\title{
Phytopathology"
}

\section{Progress on Molecular Genetics and Manipulation of Rust Fungi}

\author{
Guus Bakkeren ${ }^{1, \dagger}$ and Les J. Szabo ${ }^{2}$ \\ ${ }^{1}$ Agriculture and Agri-Food Canada, Summerland Research \& Development Centre, 4200 Hwy 97, Summerland, BC, Canada V0H 1Z0 \\ ${ }^{2}$ U.S. Department of Agriculture-Agriculture Research Service, Cereal Disease Laboratory and University of Minnesota, 1551 Lindig Street, \\ St. Paul, MN 55108, U.S.A. \\ Accepted for publication 27 November 2019.
}

\begin{abstract}
Among the thousands of rust species described, many are known for their devastating effects on their hosts, which include major agriculture crops and trees. Hence, for over a century, these basidiomycete pathogenic fungi have been researched and experimented with. However, due to their biotrophic nature, they are challenging organisms to work with and, needing their hosts for propagation, represent pathosystems that are not easily experimentally accessible. Indeed, efforts to perform genetics have been few and far apart for the rust fungi, though one study performed in the 1940s was famously instrumental in formulating the gene-for-gene hypothesis describing pathogen-host interactions. By taking full advantage of the molecular genetic tools developed in the 1980s, research on many plant pathogenic microbes thrived, yet similar work on the rusts remained very challenging though not without some successes. However, the genomics era brought real breakthrough research for the biotrophic fungi and with innovative experimentation and the use of heterologous systems, molecular genetic analyses over the last 2 decades have significantly advanced our insight into the function of many rust fungus genes and their role in the interaction with their hosts. This has allowed optimizing efforts for resistance breeding and the design and testing of various novel strategies to reduce the devastating diseases they cause.
\end{abstract}

Keywords: disease control and pest management, genetics and resistance, mycology

Rust fungi are one of the largest groups of plant pathogenic fungi. They belong to the order Pucciniales (formerly Uredinales) of the phylum Basidiomycota and represent a diverse and complex group of fungi. There are about 7,500 described species, divided into 133 recognized genera (Aime et al. 2014; Cummins and Hiratsuka 2003; Toome-Heller 2016). Rust fungi have diverse and complex life cycles (Cummins and Hiratsuka 2003). For example, Puccinia graminis f. sp. tritici, causing stem rust of wheat, is a typical macrocyclic rust fungus with five spore stages and requires two unrelated hosts (is said to be heteroecious) to complete its life cycle (Leonard and Szabo 2005). The asexual uredinial stage infects wheat, barley, and several grass species. Sexual reproduction starts with the telial stage on the gramineous host and is completed on the alternate host (Berberis spp. and Mahonia spp.). Teliospores germinate to produce basidiospores, which infect the alternate host forming pycnia (spermogonia). After transfer of pycniospores to an

${ }^{\dagger}$ Corresponding author: G. Bakkeren; guus.bakkeren@ canada.ca

Funding: This work was supported by Agriculture and Agri-Food Canada (G. Bakkeren) and the United States Department of Agriculture (L. J. Szabo).

The author(s) declare no conflict of interest.

(C) Her Majesty the Queen in Right of Canada, as represented by the Minister of Agriculture and Agri-Food Canada, 2020. opposite mating type, fertilization occurs resulting in the formation of aecia. The aeciospores then infect gramineous hosts, completing the life cycle. Wheat leaf rust, caused by the closely related species Puccinia triticina, has a very similar life cycle (Fig. 1) (Bolton et al. 2008). Melampsora lini, causing flax rust, is a macrocyclic fungus containing five spore stages, but carrying out its life cycle on a single host (therefore called autoecious) (Lawrence et al. 2007). At the other end of the spectrum are self-fertile microcyclic rust fungi that produce only two spore stages (telia and basidia), lack spermogonia, and infect a single host (for example Puccinia mesnieriana) (Anikster and Wahl 1985). The order of Pucciniales is monophyletic, and life cycle variation has occurred through convergent evolution from macrocyclic ancestors (Aime et al. 2017).

Infection of host tissue involves complex developmental processes involving cross-talk between the rust fungal pathogen and its host. Many distinct morphological changes occur during infection. An urediniospore landing on a host leaf surface, germinates to form a germ tube that develops an appressorium over a stomate, cued by its architecture (mechanosensory thigmotropism). The appressorium develops an infection peg that penetrates into the intercellular space to form a substomatal vesicle, which differentiates subsequently into an infection hypha. A haustorial mother cell is formed when the growing tip of the infection hypha comes into close contact with a mesophyll cell. Direct penetration of the mesophyll cell wall ensues upon which invagination of the plasmalemma allows 
the formation of a specific feeding structure, the haustorium. Without breaching the plant cell membrane, an intricate interface is formed consisting of an extrahaustorial membrane (modified host cell membrane), extrahaustorial matrix (EHM), haustorial wall, and haustorial membrane where exchange of compounds, nutrients and proteins (effectors) take place (for a review, see Voegele et al. 2009). During the various stages, different specific gene sets are expressed (Cuomo et al. 2017; Hacquard et al. 2010; Link and Voegele 2008; Lorrain et al. 2018b). Detailed microscopic studies of the infection processes and structural changes occurring in both pathogen and host have been published for many pathosystems since the 1960s (in particular for bean and cereal rust pathogens, e.g., Harder and Chong 1991; Lennox and Rijkenberg 1989; Mendgen 1973). Many rust fungi are capable of employing two mechanisms for entry into host plants. For rust basidiospores, entry is typically through direct penetration of an epidermal cell (of the aecial host), whereas for example in Puccinia graminis f. sp. tritici, the formation of the appressorium and penetration of the uredinial host leaf occurs at the stomate (Leonard and Szabo 2005). One known example of a variation exists in Phakopsora pachyrhizi, where the appressorium formed from germinating urediniospores directly penetrates through an epidermal cell of the soybean leaf surface (Goellner et al. 2010). In general, it illustrates that in most rust fungi both mechanisms are used, but that they are developmentally regulated.

Rust fungi cause disease across the plant kingdom including important agricultural, horticultural, and forest crops. They are infamous for causing diseases on cereals, with reports of epidemics in ancient Greek and Roman times. Wheat stem rust epidemics have continued, with the latest caused by Puccinia graminis f. sp. tritici Ug99 and 'Digalu' strains (Singh et al. 2015). Similarly, wheat leaf rust (Puccinia triticina) and wheat stripe rust (Puccinia striiformis f. sp. tritici) are worldwide the most common diseases of wheat with losses ranging from 1 to 20\% (Bolton et al. 2008; Chen et al. 2014; Savary et al. 2019). Other cereal rusts of major economic

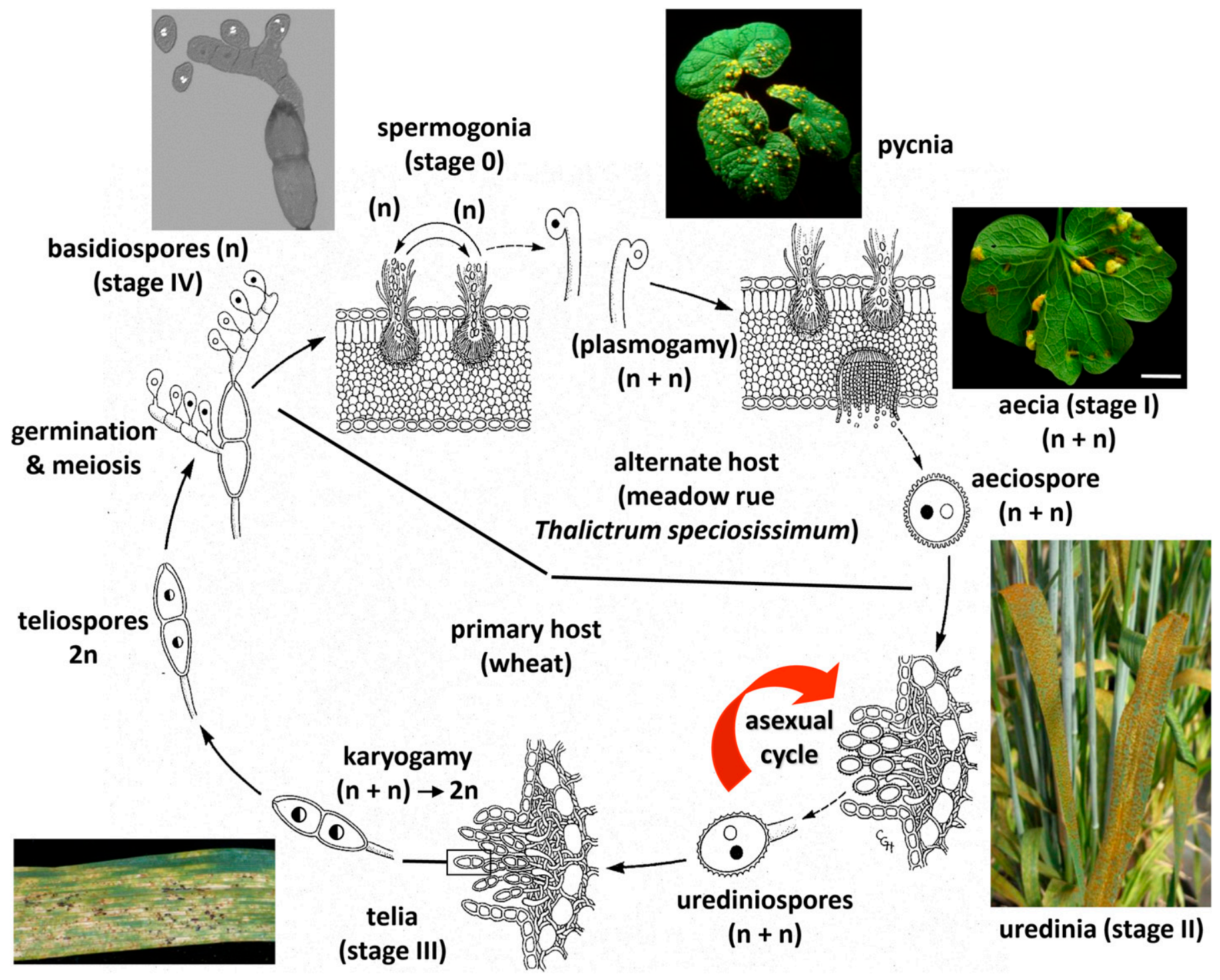

FIGURE 1

Life cycle of the macrocyclic, heteroecious wheat leaf rust pathogen, Puccinia triticina. Note that the asexual cycle on wheat can be initiated from either aeciospores or urediniospores; the latter can be wind-dispersed to new wheat hosts in a growing season, which can quickly lead to an epidemic. When conditions become unfavorable, telia from which teliospores mature are formed on senescing wheat. In the early stages of basidiospore development, each basidiospore contains a single nucleus which are the products of the two meiotic divisions (as shown in the line drawing). Subsequently, each of the four nuclei undergo a mitotic division resulting in two haploid nuclei per basidiospore as illustrated by the microscopy image (Anikster 1983). Adapted from Alexopoulos et al. (1996), drawn by C. Gubbins Hahn (John Wiley \& Sons, Reproduced by permission). Aecia and basidiospores photographs by T. Eilam, others by J. Kolmer (Reproduced by permission). 
importance include Puccinia coronata f. sp. avenae, causing oat crown rust (Nazareno et al. 2018), the barley rust Puccinia hordei (Park et al. 2015), and the common corn rust, P. sorghi (Rochi et al. 2018). Uromyces species are notorious on beans (Voegele 2006), Phakopsora pachyrhizi on soybean (Goellner et al. 2010), whereas Hemileia vastatrix, causes havoc on coffee (Talhinhas et al. 2017). $M$. larici-populina seriously affects poplar tree plantations (Duplessis et al. 2011), while other trees such as oak and myrtle suffer major losses due to Cronartium quercuum $\mathrm{f}$. sp. fusiforme and Austropuccinia psidii, respectively (Carnegie and Pegg 2018; Sniezko et al. 2014). White pine blister rust (C. ribicola) has caused serious epidemics across Asia, Europe, and North America since the late 1800s and continues to be a major disease of white pines today (Geils et al. 2010). Figure 2 illustrates a few of the common rust diseases.

The obligate biotrophic nature of rust fungi has made studying them on a molecular genetic and biochemical level challenging. While molecular genetic work on many plant pathogens flourished, comparable research on rusts has been hampered by the inability to grow most rust fungi outside of their hosts and related to that, to develop a genetic transformation system. However, the genomics revolution has been particularly beneficial for obligate fungal pathogens, allowing at least structural gene analyses, which coupled with transcriptomic and proteomic work, eased the way for performing molecular genetic studies using related heterologous

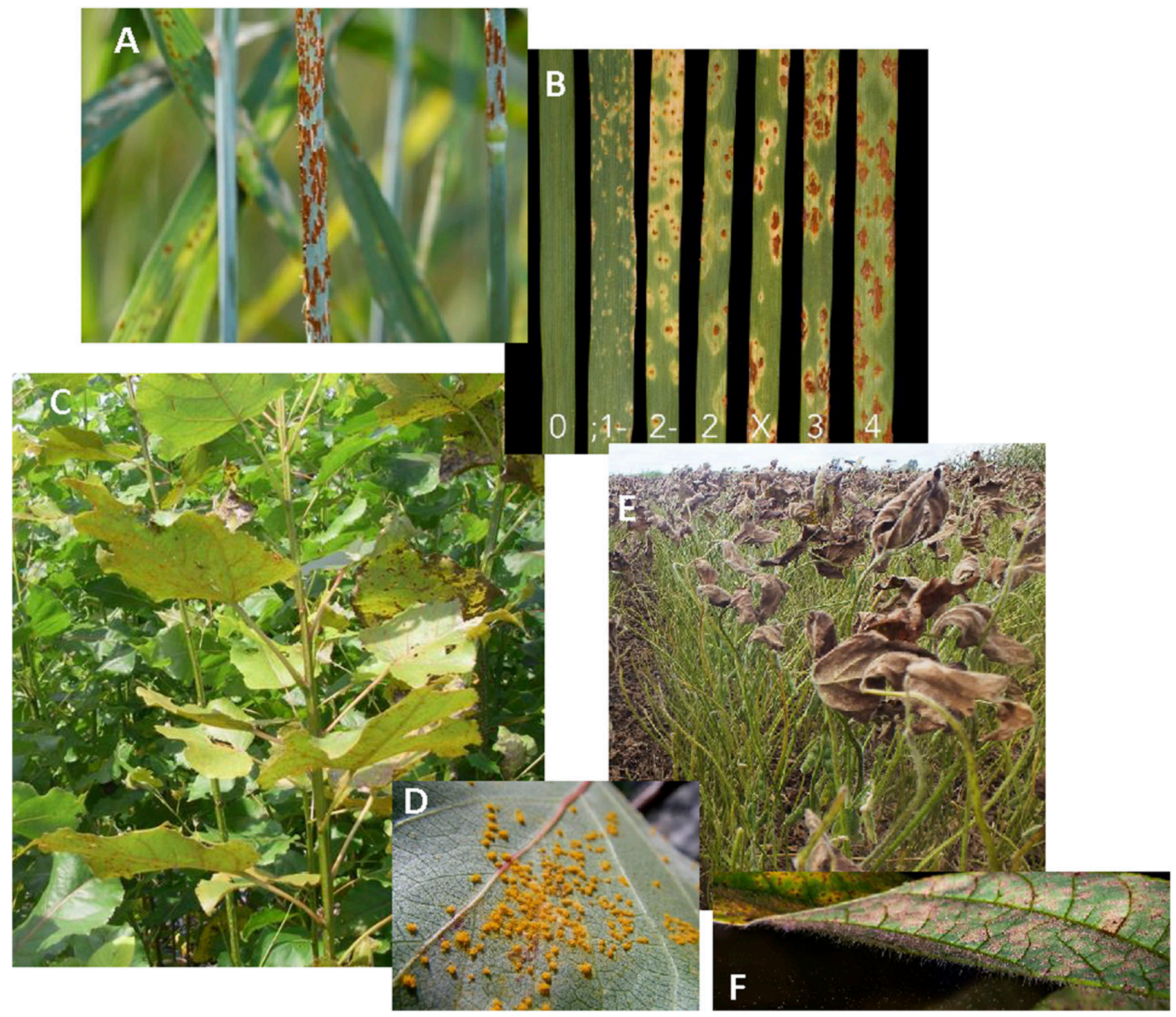

\section{FIGURE 2}

A, Stem rust uredinia on wheat, caused by Puccinia graminis f. sp. tritici. Picture courtesy of U.S. Department of Agriculture-Cereal Disease Laboratory. B, Range of infection types (ITs) of Puccinia graminis f. sp. tritici on standard wheat differential lines. ITs are scored on a scale of 0 to 4 , where $0, " ; ", 1,2$, and X are resistant and 3 and 4 are susceptible. The mesothetic IT X contains a mixture of $1 \mathrm{~s}$ and $3 \mathrm{~s}$. ITs are characteristic for Sr and AvrSr gene combinations. For example, the combination of Sr5/AvrSr5 produces IT 0; and the combination of Sr24/AvrSr24 produces an IT 2. Photograph by P. Olivera-Firpo (Reproduced by permission). C, Poplar leaf rust, a natural infection of Melampsora larici-populina on a Populus trichocarpa $\times$ Populus deltoides hybrid, and $\mathbf{D}$, close-up of M. larici-populina uredinia on wild Populus nigra. Photographs by P. Frey (Reproduced by permission). E, Asian soybean rust caused by Phakopsora pachyrhizi results in defoliation of susceptible cultivars in a Brazilian field. Photograph by M. Meyer, Embrapa Soybean Database (Reproduced by permission). F, Sporulation of Phakopsora pachyrhizi on a susceptible soybean leaf. Photograph by A. Neto, Embrapa Soybean Database (Reproduced by permission). 
systems. Since the genomics revolution, many laboratories have embarked on rust fungal research. Here, we review some of the historic research, the current state of our ability to genetically manipulate rust fungi or use workarounds to assess rust gene function, and how this impacts rust disease control and agriculture, limiting ourselves to a few well-developed and important pathosystems.

In this review, we are using the term "effectors" as defined by Kamoun (2006). In this broad definition, effectors are molecules that manipulate host cell structures and functions as to facilitate infection of and survival and proliferation in the host. Effectors are a subset of the more general pathogenicity gene products that are used by the fungus to cause disease. Pathogen genes producing products that trigger $R$ gene-mediated defense response (effector-triggered immunity) will be referred to as avirulence (Avr) genes. Based on current research, it is likely that most $A v r$ genes will encode effectors, but this definition does not preclude the possibility of an avirulence factor not being an effector. The term "virulence" has become muddled in the literature, ranging from a broad description often overlapping with general "pathogenicity," to a narrow use specific to allelic shifts in $A v r$ genes, from alleles detected by $R$ genes (avirulence) to alleles that evade detection (virulence). To further muddy the waters, "virulence" has been used to describe the quantitative differences (aggressiveness) in disease caused by isolates of the pathogen, independent of known $R$ genes. Recent reviews have highlighted the "inextricable ambiguity" in the use of these terms in the plant pathology literature (Lannou 2012; Pariaud et al. 2009). To avoid confusion, in this review, "pathogenicity" will be used for a broad description of gene products of rust fungi that provide the ability to cause any level of disease and "virulence" will be reserved for the specific qualitative phenotype due to different alleles of $A v r$ genes.

\section{CLASSICAL GENETIC ANALYSES}

Ever since the recognition that genetic factors determine the outcome of interactions between rust fungi and their hosts ("compatible," causing disease; or "incompatible," resulting from various levels of resistance), efforts to perform genetics on these fungi through sexual crosses has been attempted. Given the complex life cycle and their obligate nature, this has been challenging and only a limited number of genetic studies in a few species have been done. Nevertheless, making defined crosses is a powerful way to understand the genetics behind host-pathogen interactions and identify gene function and hence contributes to the genetic manipulation of rust fungi. Given the well-defined phenotypes observed with host differentials, these studies have typically focused on the genetics of $A v r$ genes. The pioneering work of Flor in the 1940s (see review Flor 1971) showed that host resistance is mediated by the interaction of a dominant host resistance gene $(R)$ and a corresponding dominant pathogen gene $(A v r)$ and led to the "gene-for-gene" hypothesis. This work was further developed to define a complement of $R$ and Avr genes, as well as revealing inhibitor genes in the pathogen that suppressed specific Avr genes (Lawrence et al. 1981). Extensive genetic studies have also been carried out in the Puccinia graminis f. sp. tritici-and Puccinia triticina-wheat systems, demonstrating that host resistance follows a gene-for-gene model (Loegering and Powers 1962; Samborski and Dyck 1968; Statler 1979, 2000; Williams et al. 1966). Indeed, such genetic work in cereals since the 1950s, and more recently in other crops, has laid the foundation for rust resistance gene discovery and is essential for breeding programs to control rust diseases (Long and Kolmer 1989; McCallum et al. 2016) (Fig. 2B). More recently, genetic studies combined with molecular techniques resulted in markers found linked to Avr genes in Puccinia graminis f. sp. tritici (Zambino et al. 2000), Cronartium quercuum f. sp. fusiforme (Kubisiak et al. 2011), and Puccinia striiformis f. sp. tritici (Wang et al. 2018). Recently, the availability of thousands of single nucleotide polymorphism (SNP) markers derived from genome sequencing has allowed the development of dense genetic maps and anchoring of reference genome assemblies for M. lini (Anderson et al. 2016) and M. larici-populina (Pernaci et al. 2014). Among other scorable phenotypes are color mutants that were shown in Puccinia graminis f. sp. tritici to have a genetic basis (Green 1964). Intriguingly, several studies illustrate the possible occurrence of parasexual recombination or somatic exchange of genetic material (hybridization) during host infection in Puccinia graminis f. sp. tritici, Puccinia triticina, and Phakopsora pachyrhizi (Vittal et al. 2012; Wang and McCallum 2009; Watson and Luig 1958). However, no thorough analysis of the genetic implications has been performed. This mechanism has been implicated in many studies to have contributed to the changes in virulence observed in populations, especially in nonsexual populations, i.e., where the alternate host is not present such as for Puccinia triticina in North America. See Note Added In Proofs.

\section{EARLY MOLECULAR GENETIC EFFORTS TO UNDERSTAND RUST FUNGUS INFECTION STRATEGIES}

The 1980s saw a revolution in the study of plant pathogens and the interactions with their hosts when new molecular tools were employed. This, however, remained a challenge for the obligate biotrophic rusts and mildews. Only a few laboratories embarked on efforts to apply the new techniques to unravel rust fungus gene functions. Early attempts included the use of differential screening approaches on cDNAs from bean and cereal rust fungi (Bhairi et al. 1989; Deising et al. 1995; Liu et al. 1993; Thara et al. 2003; Xuei et al. 1993). Innovative, technically challenging experimentation resulted in the construction of haustoria-specific cDNA libraries from the bean rust fungus, Uromyces fabae, revealing sets of fungal genes expressed specifically in planta (Hahn and Mendgen 1997), which combined with exquisite microscopic analyses, led to significant insight into the role of haustoria as metabolic sinks and how their metabolism may establish biotrophy (Link et al. 2005; Struck et al. 1998, 2002, 2004; Voegele et al. 2001). This included the first demonstration of a fungal protein, RTP1p, a cysteine proteinase inhibitor, expressed in haustoria, that was transferred to the host nucleus (Kemen et al. 2005; Pretsch et al. 2013).

\section{“-OMICS” BREAK-THROUGH TECHNOLOGIES TO DISCOVER THE GENETIC POTENTIAL OF RUSTS: EXPRESSED SEQUENCE TAGs (ESTs)}

Though cosmid and cDNA library construction and gene cloning from rust fungi had become feasible, this still represented a candidate gene approach and other techniques were needed to obtain more comprehensive gene inventories. As rust genomes are much larger than other fungal genomes, the generation of EST databases seemed a logical progression to obtain a better insight into the gene complements of rust fungi and were generated for several species (Catanzariti et al. 2006; Fernandez et al. 2012; Hu et al. 2007b; Link and Voegele 2008; Yin et al. 2009). These gene catalogs gave a good first look at the gene complements in various rust fungi and allowed comparative work with related (model) fungi to identify candidate pathogenicity genes for further functional studies (Xu et al. 2011).

\section{GENOMES OF RUST FUNGI}

As early as 1902, using light microscopy, estimates of the haploid chromosome numbers in various rust fungi were made, varying 
from $n=2$ to 8 (Holden and Harper 1902; McGinnis 1956). Starting in the late 1970 s, these numbers for fungi were re-examined using three dimensional reconstructions of meiotic chromosomes. This showed that the earlier studies provided underestimates and that for the rust fungi Puccinia graminis f. sp. tritici and M. lini, haploid chromosome numbers were more likely $n=18$ (Boehm and Bushnell 1992; Boehm et al. 1992) and preliminary estimates for Puccinia coronata f. sp. avenae and Puccinia triticina were $n=16$ to 18 (see review Leonard and Szabo 2005). In conjunction, genome sizes were estimated using reassociation kinetics, showing that Puccinia graminis f. sp. tritici may contain a $67-\mathrm{Mb}$ genome (Backlund and Szabo 1993), while measurements of relative DNA fluorescence provided estimates for a variety of rust fungi (Eilam et al. 1994). It became clear that rust genomes were much larger than other fungal genomes, were highly variable, had larger numbers of haploid chromosomes, and contained a high amount of repetitive DNA and/or transposable elements (TEs), all of which explained why the many molecular genetic approaches proved so challenging.

\section{WHOLE GENOME SEQUENCING}

With next-generation sequencing technologies developing fast, sequencing of the genomes of rust fungi became affordable, even though more recent assessments indicate them to be in the range of 80 to $300 \mathrm{Mbp}$, with upper limits as high as $2 \mathrm{Gbp}$ and hence significantly larger than those of many other fungal species (Aime et al. 2017; Tavares et al. 2014). The first genomes to be sequenced were those of Puccinia graminis f. sp. tritici and M. larici-populina (Duplessis et al. 2011), soon followed by several others (reviewed in Aime et al. 2017; Bakkeren et al. 2016; Duplessis et al. 2014). "Third-generation" or "long-read" sequencing (on PacBio, NanoPore, 10x Genomics, and Hi-C platforms) and new assembly software are rapidly improving the previously rather fragmented published rust genome assemblies, such as the new near-complete, haplophased genomes of Puccinia coronata f. sp. avenae (Miller et al. 2018) and Puccinia striiformis f. sp. tritici (Schwessinger et al. 2018). For M. larici-populina, this has led to a revised genome size of $\sim 110 \mathrm{Mbp}$ (from $101 \mathrm{Mbp}$ ) with its scaffolds anchored onto 18 linkage groups, thanks to a genetic map obtained from a selfing of the reference genome isolate (S. Duplessis, personal communication; JGI website https://mycocosm.jgi.doe.gov/Mellp2_3/Mellp2_ 3.info.html). An M. lini v2 genome assembly estimated to be $\sim 500$ Mbp, including both haplotypes and anchored to the genetic map of 26 linkage groups (Anderson et al. 2016), will be published soon (P. Dodds, personal communication), as will be a Puccinia triticina v3 genome (J. Fellers and G. Bakkeren, unpublished data). The estimated 1.2 Gbp genome of the myrtle rust fungus, Austropuccinia psidii, was recently sequenced using the Chromium 10x technology (McTaggart et al. 2018), and sequencing of three isolate genomes of the soybean rust fungus, Phakopsora pachyrhizi, estimated at $1 \mathrm{Gbp}$, has been completed (JGI; S. Duplessis, P. van Esse, and R. Voegele, personal communication).

Rust fungal genomes proved to be significantly larger than many of the currently sequenced genomes from oomycetes and other fungi, except other known biotrophs such as the powdery mildew fungi. These genome expansions seem to be caused by repeats and TEs which among various genera can range from $30 \%$ to $74+\%$ of the genome; the high variation is in part due to the sequencing technology and assembly software used (Aime et al. 2017). But even among closely related species such as Puccinia triticina and Puccinia graminis f. sp. tritici, though a certain synteny was preserved, the dynamic nature of the genomes due to repeats and TEs was illustrated (Cuomo et al. 2017; Fellers et al. 2013). A more accurate picture of TE content and distribution will be obtained with the advent of long-read sequencing technologies allowing complete genome assemblies (Miller et al. 2018; Schwessinger et al. 2018). Depending on the software and parameters used for predictions, gene numbers vary among the currently sequenced rust fungi, from 14,880 to 27,578 , with an average of $18 \mathrm{~K}$ for most (Aime et al. 2017). What is striking among these genomes is the large number of genes without any annotated function. For example, comparing orthologs among the three wheat rusts, Puccinia triticina, Puccinia graminis $\mathrm{f}$. sp. tritici, and Puccinia striiformis f. sp. tritici produced $5,443,4,901$, and 8,955 species-specific genes, respectively, whereas overall less than half of the genes in each rust fungus was conserved among other basidiomycetes (Cuomo et al. 2017). This suggests that extensive mutation/evolution has occurred. This could be a result of the strict biotrophic niches they inhabit, including the need for the heteroecious species to be able to infect two very different hosts, and the dikaryotic nature of the genomes. Other major findings have been gene losses in pathways for nitrate and sulfate assimilation, the presence of expanded gene families coding for transporters of various substrates, fewer plant cell walldegrading enzymes, and larger predicted secretomes as a percentage of the whole proteome, when comparing to nonbiotrophs; these are likely all hallmarks of adaptive mechanisms to obligate biotrophy (Aime et al. 2017; Duplessis et al. 2011; Lo Presti et al. 2015). It is tempting to speculate that the dynamic nature of the TEs plays an important role in such adaptations, including overcoming resistance mechanisms (Barsoum et al. 2019).

Understandably, the main focus has been on generating genomic resources for rust fungi affecting agriculture and forestry crops, but with the enormous variability in the order Pucciniales, much could be learned from comparative genomics. To this end, the Joint Genome Institute, with support of 12 research groups worldwide, has embarked on generating reference genomes from 50 rust fungal species of diverse origins belonging to different family-level lineages comprising this order (Aime et al. 2017), including many of economic importance (https://jgi.doe.gov/csp-2018-duplessisreference-genomes-50-rust-fungi/). Comparisons are expected to answer questions concerning taxonomy, host range, specificity and selection, pathogenicity, diversification, and genome expansion and will likely have direct bearing on the development of novel strategies for crop protection.

\section{TRANSCRIPTOMES, GENOME-WIDE ASSOCIATION, AND COMPARATIVE STUDIES}

The low cost of sequencing and the availability of genome sequences also allowed the generation of comprehensive transcriptomes representing various rust fungus developmental stages, including different infection stages, and their comparisons. It goes beyond the scope of this review to list the dozens of studies here, except to say that they have quickly supplanted all the EST work. These comparative studies have provided essential insight into genetic programs involved in spore germination and host infection strategies (reviewed in Lorrain et al. 2019).

Since genome sequences from many isolates are now available for several species, variants in genes/proteins can be associated with phenotypes to find candidate genes for functional verification. A small-scale genome-wide association study approach to link changes at the transcript level to changes in virulence profiles on defined wheat cultivars, resulted in the identification of 15 Puccinia triticina candidate secreted effectors potentially recognized by eleven different leaf rust resistance ( $L r)$ genes (Bruce et al. 2014). A larger scale phenotype-genotype association analysis resulted in the identification of a small subset of candidate effectors potentially interacting with $\operatorname{Lr} 20$ (Wu et al. 2017). A similar comparative analysis in an $M$. larici-populina population revealed candidate effectors widely present and under selection pressure as the most likely candidates for screening (Persoons et al. 2014). Large 
genomic resources can also be compared to assess the genetic potential of rust fungi indirectly, especially when transcriptomes from interactive stages, that is transcriptomes from both the pathogen and host are compared. In one study on the infection of wheat by Puccinia graminis f. sp. tritici, this led to the description of gene coexpression networks and the identification of candidate effectors potentially involved in the interaction (Rutter et al. 2017). All these computational approaches are identifying candidate genes from rust fungi involved in the interaction with their hosts and provide leads for functional analyses and potential targets for disease control.

\section{PROTEOMICS}

EST inventories opened the door to extensive proteomics work, such as for bean rusts (Cooper et al. 2007, 2016; Luster et al. 2010; Stone et al. 2012) and Puccinia triticina (Song et al. 2011). More comprehensive proteomes were identified using whole genome sequences. An innovative technique used purified Puccinia triticina haustoria to generate a monoclonal antibody in mice that was subsequently used to isolate to near homogeneity by immunoprecipitation, haustoria from Puccinia triticina-infected wheat leaves. These antibody-purified Puccinia triticina haustoria revealed a content of 1,192 identified proteins, among which 140 candidate secreted effector proteins (CSEPs) (Rampitsch et al. 2015). When relative protein amounts among those 140 CSEPs is compared with the normalized transcript levels of the corresponding genes in wheat leaves 6 days after infection with Puccinia triticina, discrepancies between correlations of up to 2 orders of magnitude are observed for certain genes (G. Bakkeren, unpublished data). Similar observations were made in wheat infected with Puccinia striiformis f. sp. tritici (Figure 7 in Zhang et al. 2019). This shows that protein levels often do not correlate well with transcript levels (Gygi et al. 1999), and that quantitative proteomic analyses are needed in conjunction with transcriptomes. Indeed, when establishing "secretomes" using proteomic analyses, sometimes more than $50 \%$ do not conform to predicted signal peptidecontaining canonical ER-Golgi secreted proteins in the sequenced genomes, indicating the existence of alternative pathways and mechanisms and a potential larger "secretome" than currently predicted (Agrawal et al. 2010). In addition, protein fragments have been mapped to positions on the Puccinia triticina genome where no genes are predicted (C. Rampitsch, personal communication), even though transcripts are often found, such as for a mating pheromone (Cuomo et al. 2017). It is anticipated that the various "omics" datasets and future gene calling algorithms and machine learning approaches will provide better annotations. Proteomics is also valuable in that posttranslational modifications such as phosphorylation, shown to be responsible for major changes in activity levels, can be revealed (Rampitsch and Bykova 2012).

\section{CHASING EFFECTORS}

In the 1990s, various biochemical attempts were made to isolate $A v r$ gene products from rust fungi by isolating race-specific elicitors of the hypersensitive response (HR; necrosis) in cultivars having specific $R$ genes. Intercellular (apoplast) washing fluid was analyzed but no corresponding genes were identified (reviewed in Staples 2000). This approach is being revisited in various pathosystems using more sensitive proteomic analyses.

Small secreted proteins were identified in M. lini after differential screening of cDNAs from an infected host and represented Avr genes conditioning resistance on flax with corresponding $R$ genes L5, L6, or $L 7$ (Dodds et al. 2004). These Avr genes were shown to be expressed in haustoria and the corresponding AVR proteins delivered to and active within the host cell. This work finally proved the molecular basis of the gene-for-gene hypothesis as proposed by Flor in 1947 (reviewed in Flor 1971) in the original model flax-flax rust pathosystem and was a first for rust fungi. Since haustoria are thought to be central hubs of the biotrophic interaction with crucial metabolite exchange and effector secretion, their isolation has helped to identify suites of effectors using ESTs and transcriptomic data (Catanzariti et al. 2006; Hahn and Mendgen 1997; Thara et al. 2003), and proteomics (Cooper et al. 2016; Rampitsch et al. 2015). Moreover, with the extensive genomic resources available, machine-learning algorithms tuned to rust fungal genes have been developed to generate lists of potential effectors, including their predicted localization (de Carvalho et al. 2017; Petre et al. 2014; Saunders et al. 2012; Sperschneider et al. 2017, 2018a, b). The rust fungal AVR effectors cloned to date are recognized by $R$ gene products in the host cytoplasm (Anderson et al. 2016; Catanzariti et al. 2006; Chen et al. 2017; Dodds et al. 2004; Salcedo et al. 2017), but for Puccinia graminis f. sp. tritici, two AVR effectors are found localized to the urediniospore surface and interacting at the barley leaf surface with the $R P G 1$ resistance protein to trigger an HR (Nirmala et al. 2011). Apart from the requirement for the presence of a classical $\mathrm{N}$-terminal signal peptide sequence as a criterion for effector selection, length exclusion above 300 amino acids is often used. Indeed, most effectors studied are small secreted proteins including many proven AVRs; however, PgtAVRSr35 is 578 amino acids long (Salcedo et al. 2017). With the availability of large genomic resources, we need to keep an open mind when attempting to identify candidate effectors.

Effector suites have been associated with virulence potential. The importance of understanding and detecting potential virulence shifts in populations has been recognized since the early 1900s with extensive annual field surveys of cereal rusts, collection of isolates and subsequent phenotyping on differential cultivars $(R$ gene inventory) to identify races (Avr gene repertoire). This is crucial for the management of rust diseases and has been the bed rock of resistance breeding in cereals for over 70 years and has been emulated for other economically important pathosystems. Indeed, extensive studies on the population genetics of rust fungi at regional and more recently global scales have been and are being done. Within the context of this review, we highlight the advances in DNA sequencing and bioinformatics that have allowed population studies and characterization of regional and global lineages based on neutral SNPs in thousands of loci. With an increasing number of isolates sequenced, extensive SNP databases are becoming available for a few rust fungal species, allowing the development of rapid and cost-effective SNP-based tools for genotyping, including arrays able to detect thousands of loci, or analysis of transcripts or a set of discriminating fungal genome regions from infected leaf samples, even in portable devices (Hu et al. 2019; Hubbard et al. 2015) for monitoring the global spread of new harmful lineages such as Puccinia graminis f. sp. tritici $\mathrm{Ug} 99$ or high temperature-adapted, more virulent Puccinia striiformis f. sp. tritici lineages (BuenoSancho et al. 2017; Newcomb et al. 2016; Olivera et al. 2015; Radhakrishnan et al. 2019). These are now invaluable resources for the association of (virulence) phenotypes to (effector suite) genotypes to inform rust disease management.

\section{FUNCTIONAL ANALYSIS OF RUST FUNGUS GENES}

For rust fungi, publicly available genomic resources are increasing fast, yet proper genetic manipulation and direct means of functional gene analysis in the rust fungi themselves, though important, is still very challenging. Over the years there have been several efforts to develop genetic transformation technology. Using the beta-glucuronidase (GUS) or green or red fluorescent protein (GFP, DsRed) genes as a reporter under control of various 
promoters, particle bombardment of urediniospores resulted in transient transformation of Uromyces spp. (Bhairi and Staples 1992; Djulic et al. 2011), Puccinia graminis f. sp. tritici (Fehser and Moerschbacher 2011; Schillberg et al. 2000), and Puccinia triticina (Webb et al. 2006). However, detection of these low frequency events would be more efficient if selectable markers were available. Although there are reports employing hygromycin, and fungicides such as benomyl and carboxin (Djulic et al. 2011; Wirsel et al. 2004), none have yet resulted in effective selection in planta. For the biotrophic rust fungi, selection was achieved in M. lini while it was growing in flax, using Agrobacterium tumefaciens to introduce an AvrL567 gene silencing construct that resulted in stable transformants (Lawrence et al. 2010). The silencing of this Avr gene no longer prevented the fungus from growing in flax lines having the recognizing $R$ gene and hence allowed only transformed rust fungi to sporulate. This provided a tight selection. However, the use of a combination of genes involved in fungus-plant interaction as a transformation selection system may not be ideal to study the function of other genes involved in (early) fungal-host interactions. It seems that it is just a matter of time before the right conditions and combinations of genes are found to achieve reproducible transformation. For example, CRISPR technology may be used to mutate interaction-inhibitory factors or dominant $A v r$ genes as selectable markers.

Since $A v r$ genes are typically dominant and the matching $R$ genes provide an excellent selection during the needed biotrophic growth, the use of induced/engineered or natural mutations in Avr genes has also been exploited successfully. The study transforming Puccinia triticina mentioned above (Webb et al. 2006), generated random integration events and used subsequent selection on various $R$ gene containing cultivars to assess the feasibility of disrupting a matching Avr gene for further cloning and analysis. Though in that study genetic transformation was shown to be stable over several infection cycles in the wheat host, it did not lead to the cloning of an $A v r$ gene. The idea of inducing mutations was used in another study where Puccinia graminis f. sp. tritici urediniospores were treated with ethylmethane sulfonate, resulting in mutants with altered virulence on a wheat cultivar harboring resistance gene $\mathrm{Sr} 35$. The genomes of the wild-type avirulent Puccinia graminis f. sp. tritici isolate and 15 confirmed virulent mutants were sequenced and compared, leading to a candidate secreted effector gene that was shown to represent PgtAvrSr35 (Salcedo et al. 2017). Since the rust fungi are dikaryotic, containing two haplotypes for most of their life cycle, relying on mutation analysis to identify (dominant) gene function may only work for genes in a heterozygous state. This concept was exploited in a naturally emerged mutant of Puccinia graminis f. sp. tritici that had become virulent on a wheat cultivar harboring $S r 50$. Upon genome sequencing, a 2.5 million base pair region was identified where loss of heterozygosity had occurred, which was confirmed to result from a duplication of one haplotype in that region. Again, focusing on small secreted protein genes located in that region, only a few candidates were identified upon comparing alleles in the population, one of which was functionally shown to represent PgtAvrSr50 (Chen et al. 2017; discussed further below).

In the previous two studies, confirmation of the avirulence function of the effectors was achieved in a heterologous system: coexpressing $A v r$ candidates and matching $R$ genes, delivered via Agrobacterium tumefaciens in Nicotiana benthamiana, triggered a visible HR. This heterologous system has been successfully used for effectors from various rust fungi to investigate their localization (using fluorescent chimeras and confocal microscopy) and possible host targets to infer their potential functions (reviewed in Lorrain et al. 2018a). Arabidopsis thaliana has also been used for testing M. larici-populina effector functions. When several were expressed as transgenes, they promoted susceptibility to several other pathogens (Germain et al. 2018). Indeed, suppression of host defense responses has been shown to be a general function of many pathogen effectors. On the other hand, only for few rust fungi, a number of effectors were verified to suppress defenses in their natural host after their delivery by various engineered microbes, including various Pseudomonas species using their Type III Secretion System (Liu et al. 2016; Qi et al. 2016, 2018; Ramachandran et al. 2017; Zhao et al. 2018). Using such microbes for delivery, having verified they do not elicit strong nonhost responses, effectors from a few rust pathogens have also been tested in their natural hosts to investigate their potential to trigger defense responses (Dodds et al. 2004; Liu et al. 2016; Maia et al. 2016; Upadhyaya et al. 2014). To verify the avirulence function of PgtAvrSr35, an E. coli-produced protein fraction was infiltrated in wheat leaves to trigger an HR (Salcedo et al. 2017). And the barley stripe mosaic virus (BSMV) was used to indicate PgtAVRSr50 function in $\operatorname{Sr} 50$ wheat (Chen et al. 2017). Another potential homologous expression system for testing cereal rust fungal genes is the foxtail mosaic virus, recently engineered to express larger proteins ( $>600$ amino acids) in cereals (Bouton et al. 2018). These natural host approaches can likely be used as effector-based screening methods to discover novel resistances in cultivars and (wild) germplasm to assist breeding programs.

Alternative methods to validate rust fungal gene functions have included heterologous expression in other fungal organisms for biochemical studies and to revert clear phenotypes caused by a deletion mutant in a well-described gene. For example, a bean rust Uromyces fabae plasma membrane ATPase gene was able to complement a homologous ATPase mutant in Saccharomyces cerevisiae and allowed measurements of its enzymatic activity (Struck et al. 1998), and the Uromyces fabae invertase INVI gene was expressed in the same yeast and Pichia pastoris to study its activity associated with the secreted gene product INV1p (Voegele et al. 2006). Similarly, MAPK deletion mutants kpp2/ubc3 and kpp6 in the corn smut pathogen Ustilago maydis were used to show functional complementation by the homologous PtMAPK1 gene from the wheat leaf rust fungus (Hu et al. 2007a). In that study, complementation was functional when the PtMAPK1 gene was expressed from the Ustilago maydis $H s p 70$ promoter, but also from its endogenous PtMAPK1 promoter, indicating that Puccinia triticina promoter elements were recognized by the Ustilago transcription machinery. Complementation of mutations in other fungal organisms such as Fusarium graminearum, Magnaporthe oryzae, and Schizosaccharomyces pombe has since been emulated for various other rust fungus genes (Guo et al. 2011; Jiao et al. 2017; Zhu et al. 2018).

\section{HOST-INDUCED GENE SILENCING (HIGS) AND SMALL RNA SIGNALING}

More recently, one of the most successful general, but indirect ways to test functions of rust genes is through gene silencing, using the host for expression and generation of silencing molecules. Originally shown to work for the barley and wheat-Blumeria pathosystems (Nowara et al. 2010), HIGS was quickly adapted for rust fungi either using the BSMV for delivery of sense and antisense molecules that could form duplexes (Panwar et al. 2013b; Yin et al. 2011) or using Agrobacterium tumefaciens to transiently express hairpin fold-back molecules in the host cells (Panwar et al. 2013a). Though the production of siRNA molecules in wheat could be shown, as well as a major reduction in mRNA levels of the fungal gene targeted, the exact mechanism is currently unknown but likely relies on the uptake of siRNAs by the fungal haustoria. Silencing rust fungus genes involved in establishing disease or affecting host defense, leads to clear measurable phenotypes. Moreover, when targeting rust fungus genes essential for pathogenicity, this approach could complement other rust disease reduction strategies 
in agriculture when the silencing constructs are stably integrated in the wheat host (Panwar et al. 2018; Qi et al. 2017). Targeting many of the effectors has not resulted in clear phenotypes, likely because of functional redundancy or cumulative (small) roles in pathogenicity (Yin et al. 2015), though some can be shown to contribute substantially to levels of disease development (Liu et al. 2016; Yin et al. 2019). This should be different when silencing a dominant avirulence gene. It would be interesting to target genes involved in the change of cell wall structure or components known to occur in fungi during infection, likely to prevent recognition of such components to trigger defenses. This was shown using microscopy for Puccinia graminis f. sp. tritici and Uromyces fabae, where cell wall content was changed from chitin to chitosan (El Gueddari et al. 2002). In the tomato pathogen Cladosporium fulvum, the AVR4 effector masks chitin on fungal cell surfaces (Westerink et al. 2002); silencing such genes would expose fungi to the host immune responses, possibly triggering broad defense responses (OliveiraGarcia and Deising 2013).

As shown in other plant-microbe interactions, the existence of small RNA molecules and their potential role in communication between the pathogen and its host to promote disease or fine-tune defense was also demonstrated for rust pathosystems. Though several studies identify host regulatory RNAs whose expression is affected during rust fungus infections, only a few have investigated rust fungus-specific small RNAs. Targets/genes whose sequence match and are therefore potentially regulated by small RNAs, were predicted in several rust fungi. These included kinases, effector genes and TEs with potential to influence transcription of genes nearby. In addition, matches to genes in the host were found, one of which was experimentally confirmed to be involved in the interaction (Mueth et al. 2015; Sperschneider et al. 2018c; Wang et al. 2017). Interfering with (crucial) regulatory small RNAs opens up new possible strategies for the genetic manipulation and functional analysis of rust fungus genes. When fungal small RNAs that function as general pathogenicity factors are targets for the HIGS technology, it could provide crop protection; targeting multiple small RNAs with different functions at once could be difficult to overcome by the fungus (through mutation).

\section{CONCLUSIONS AND IMPACT ON CROP PROTECTION}

Over the last 20 years, research on rust fungi has rapidly expanded due to the advent of new genomic technologies. Genomes of rust fungi have been shown to be much larger and more complex than other fungi, with highly variable haplotypes among dikaryotic genomes and genome sizes ranging from $87 \mathrm{Mb}$ to $2 \mathrm{~Gb}$. Rapid progress is being made on developing complete chromosome assemblies for a few rust fungi. These genomes contain high levels of repetitive elements and large gene families, including very large secretomes thought to be critical for the biotrophic life style of these plant pathogens. For several species, genome data from several isolates, transcriptomes, and proteomes now exist, allowing the generation of comprehensive pan-genomes and comparative analyses. This provides insight into the variability of fungal genomes and population structures including virulence shifts and how these relate to the presence and emergence of effector variants. This will likely provide new insights that will allow more effective deployment of host $R$ genes. Moreover, genetic and molecular research on the biotrophic rust fungi, though challenging, is opening avenues for novel crop protection strategies. The first Avr genes have been cloned and it has been shown that the effector proteins they encode can directly interact with their cognate $R$ gene proteins within the host cell or on the cell surface; there is as of yet, no evidence of indirect interactions with R-guarded targets in these rust pathosystems. Progress has been made on functional assays using a wide variety of different approaches, and hence, new AVR effector inventories can assist in isolating and recognizing $R$ genes including in the search for novel, potentially more durable ones among wild germplasm. Among effectors not interacting with $R$ genes, some have been shown to be involved in nutrient uptake at the haustorium interface or to suppress plant host immune responses. This latter set of effectors, and other genes crucial for the interaction with the host, have provided candidates for silencing using the HIGS technology to interfere with the ability of the rust fungus to infect and cause disease; this technology may also be successful when choosing fungal small regulatory RNAs and their target genes that contribute to pathogenicity. Unraveling the function of these novel fungal genes may lead to the development of novel classes of fungicides. Lastly, fungal effector targets in the hosts may represent susceptibility genes that could be modified by genome editing to reduce infection and disease.

\section{FUTURE CHALLENGES}

Despite the enormous progress on the generation of genomic resources for the rust fungi, there are still no "gold standard," haplophased and chromosome-based genome assemblies with comprehensive gene annotations, including proper allele identification, and analyses of repeats and the extremely large TE content. This is a prerequisite for further meaningful resequencing of isolates with the understanding that this will result in the generation of pan-genomes for species and forma speciales to assess the gene complement and precise allelic variants, with a focus on effectors. For this to be most effective, more detailed worldwide information on virulence profiles (on host cultivars) and population structures (genetic lineages) is needed. Sequencing Avr genes in populations could assess the presence of effectors in a heterozygous state, posing a higher risk of overcoming the matching $R$ genes through mutation. However, until Avr genes, as well as the avirulent and virulent alleles are well defined, genotyping will only be predictive of race phenotypes in populations where recombination (sexual or somatic) does not occur or only occurs infrequently.

A major challenge remains the lack of a suitable and reproducible genetic transformation technology for rust fungi to assess gene functions. Some current approaches employing GUS or GFP look promising but the limited choice of selectable markers during biotrophy is thwarting efforts; gene silencing or editing of certain selectable target genes may overcome this but the current choice of $A v r$ genes for selection may compromise testing pathogenicity and other effector genes. A reproducible transformation system would allow for direct gene function testing, which now is mainly done in heterologous systems.

Classical genetic experimentation through defined crosses is still a powerful approach and should be revisited with the genomic resources now available. Much of the effector work has focused on genes encoding small secreted proteins. It is now clear that this is an important class of effectors, but not the only one. Genetic studies will provide one means for identifying these additional classes of $A v r$ genes. There is a growing amount of literature showing quantitative differences (aggressiveness) between isolates of rust fungi of the same race phenotype (Pariaud et al. 2009). These studies examine a range of traits including infection efficiency, latent period, and sporulation rate. Defining the genetics behind these traits will provide handles to begin to elucidate the mechanisms responsible. One of the hurdles has been the difficulty of measuring these phenotypes.

Several intriguing questions in rust fungi (and other biotrophs) remain unresolved to date. Haustoria are considered the main bodies where effector secretion and exchange of metabolites and small RNAs occur. This involves a complex, poorly understood interface consisting of a haustorial wall, an EHM, and a modified host membrane; sealed off by a specialized structure, the neckband, 
it is considered a modified apoplastic space. However, it is likely that the expanding intercellular hyphal network also contributes to the interactions with host cells. For example, in Ustilago species, which grow within hosts both inter- and intracellularly as biotrophs, no haustoria are found and hyphae are therefore thought to perform exchange of nutrients and delivery of effectors (Lanver et al. 2017). Crucial information is lacking on how fungal effectors are delivered, either into the apoplast (EHM) and selectively taken up, or (a subset) delivered directly into the host cytoplasm. What are the functions of the various interfaces? Are these processes active or passive? Also, the developmental regulation of the different stages of the life cycle of the rust fungi are unknown. New genomic technologies such as single cell transcriptomics may identify genes involved in such transitions. The mechanisms involved could provide targets for pathogen control.

\section{NOTE ADDED IN PROOF}

$\mathrm{Li}$ et al. (2019) recently provided proof of complete nuclear exchange, during somatic hybridization, among dikaryotic strains of $P$. graminis f. sp. tritici without apparent chromosomal recombination between nuclei. Apart from providing an explanation for the highly variable haplotypes seen among sequenced rust fungus genomes, it provides a cautionary note for assigning relatedness through phylogenomic analyses based on non-phased SNP data.

\section{ACKNOWLEDGMENTS}

We thank Ralf Voegele and Peter Dodds and three anonymous reviewers for critical comments on the manuscript.

\section{LITERATURE CITED}

Agrawal, G. K., Jwa, N.-S., Lebrun, M.-H., Job, D., and Rakwal, R. 2010. Plant secretome: Unlocking secrets of the secreted proteins. Proteomics 10: 799-827.

Aime, M. C., McTaggart, A. R., Mondo, S. J., and Duplessis, S. 2017. Phylogenetics and phylogenomics of rust fungi. Pages 267-307 in: Advances in Genetics. Vol. 100. J. P. Townsend and Z. Wang, eds. Academic Press, Cambridge, MA.

Aime, M. C., Toome, M., and McLaughlin, D. J. 2014. Pucciniomycotina. Pages 271-294 in: Systematics and Evolution: Part A. D. J. McLaughlin and J. W. Spatafora, eds. Springer, Berlin, Heidelberg.

Alexopoulos, C. J., Mims, C. W., and Blackwell, M. M. 1996. Introductory Mycology, 4th ed. John Wiley \& Sons, New York.

Anderson, C., Khan, M. A., Catanzariti, A.-M., Jack, C. A., Nemri, A., Lawrence, G. J., Upadhyaya, N. M., Hardham, A. R., Ellis, J. G., Dodds, P. N., and Jones, D. A. 2016. Genome analysis and avirulence gene cloning using a high-density RADseq linkage map of the flax rust fungus, Melampsora lini. BMC Genomics 17:667.

Anikster, Y. 1983. Bincucleate basidiospores-A general rule in rust fungi. Trans. Brit. Mycol. Soc. 81:624-626.

Anikster, Y., and Wahl, I. 1985. Basidiospore formation and self-fertility in Puccinia mesnieriana. Trans. Br. Mycol. Soc. 84:164-167.

Backlund, J. E., and Szabo, L. J. 1993. Physical characteristics of the genome of the phytopathogenic fungus Puccinia graminis. Curr. Genet. 24:89-93.

Bakkeren, G., Joly, D. L., and Duplessis, S. 2016. Editorial: Genomics research on non-model plant pathogens: Delivering novel insights into rust fungus biology. Front. Plant Sci. 7:216.

Barsoum, M., Sabelleck, B., Spanu, P. D., and Panstruga, R. 2019. Rumble in the effector jungle: Candidate effector proteins in interactions of plants with powdery mildew and rust fungi. Crit. Rev. Plant Sci. 38:255-279.

Bhairi, S. M., and Staples, R. C. 1992. Transient expression of the betaglucuronidase gene introduced into Uromyces appendiculatus uredospores by particle bombardment. Phytopathology 82:986-989.

Bhairi, S. M., Staples, R. C., Freve, P., and Yoder, O. C. 1989. Characterization of an infection structure-specific gene from the rust fungus Uromyces appendiculatus. Gene 81:237-243.

Boehm, E. W. A., and Bushnell, W. R. 1992. An ultrastructural pachytene karyotype for Melampsora lini. Phytopathology 82:1212-1218.

Boehm, E. W. A., Wenstrom, J. C., McLaughlin, D. J., Szabo, L. J., Roelfs, A. P., and Bushnell, W. R. 1992. An ultrastructural pachytene karyotype for Puccinia graminis f. sp. tritici. Can. J. Bot. 70:401-413.
Bolton, M. D., Kolmer, J. A., and Garvin, D. F. 2008. Wheat leaf rust caused by Puccinia triticina. Mol. Plant Pathol. 9:563-575.

Bouton, C., King, R. C., Chen, H., Azhakanandam, K., Bieri, S., Hammond-Kosack, K. E., and Kanyuka, K. 2018. Foxtail mosaic virus: A viral vector for protein expression in cereals. Plant Physiol. 177:1352-1367.

Bruce, M., Neugebauer, K. A., Joly, D. L., Migeon, P., Cuomo, C. A., Wang, S., Akhunov, E., Bakkeren, G., Kolmer, J. A., and Fellers, J. P. 2014. Using transcription of six Puccinia triticina races to identify the effective secretome during infection of wheat. Front. Plant Sci. 4:520.

Bueno-Sancho, V., Persoons, A., Hubbard, A., Cabrera-Quio, L. E., Lewis, C. M., Corredor-Moreno, P., Bunting, D. C. E., Ali, S., Chng, S., Hodson, D. P., Madariaga Burrows, R., Bryson, R., Thomas, J., Holdgate, S., and Saunders, D. G. O. 2017. Pathogenomic analysis of wheat yellow rust lineages detects seasonal variation and host specificity. Genome Biol. Evol. 9:3282-3296.

Carnegie, A. J., and Pegg, G. S. 2018. Lessons from the incursion of myrtle rust in Australia. Annu. Rev. Phytopathol. 56:457-478.

Catanzariti, A. M., Dodds, P. N., Lawrence, G. J., Ayliffe, M. A., and Ellis, J. G. 2006. Haustorially expressed secreted proteins from flax rust are highly enriched for avirulence elicitors. Plant Cell 18:243-256.

Chen, J., Upadhyaya, N. M., Ortiz, D., Sperschneider, J., Li, F., Bouton, C., Breen, S., Dong, C., Xu, B., Zhang, X., Mago, R., Newell, K., Xia, X., Bernoux, M., Taylor, J. M., Steffenson, B., Jin, Y., Zhang, P., Kanyuka, K., Figueroa, M., Ellis, J. G., Park, R. F., and Dodds, P. N. 2017. Loss of AvrSr50 by somatic exchange in stem rust leads to virulence for $\operatorname{Sr} 50$ resistance in wheat. Science 358:1607-1610.

Chen, W., Wellings, C., Chen, X., Kang, Z., and Liu, T. 2014. Wheat stripe (yellow) rust caused by Puccinia striiformis f. sp. tritici. Mol. Plant Pathol. 15:433-446.

Cooper, B., Campbell, K. B., Beard, H. S., Garrett, W. M., and Islam, N. 2016. Putative rust fungal effector proteins in infected bean and soybean leaves. Phytopathology 106:491-499.

Cooper, B., Neelam, A., Campbell, K. B., Lee, J., Liu, G., Garrett, W. M., Scheffler, B., and Tucker, M. L. 2007. Protein accumulation in the germinating Uromyces appendiculatus uredospore. Mol. Plant-Microbe Interact. 20:857-866.

Cummins, G. B., and Hiratsuka, Y. 2003. Illustrated Genera of Rust Fungi. American Phytopathological Society, St. Paul, MN.

Cuomo, C. A., Bakkeren, G., Khalil, H. B., Panwar, V., Joly, D., Linning, R., Sakthikumar, S., Song, X., Adiconis, X., Fan, L., Goldberg, J. M., Levin, J. Z., Young, S., Zeng, Q., Anikster, Y., Bruce, M., Wang, M., Yin, C., McCallum, B., Szabo, L. J., Hulbert, S., Chen, X., and Fellers, J. P. 2017. Comparative analysis highlights variable genome content of wheat rusts and divergence of the mating loci. G3: Genes|Genomes|Genetics 7:361-376.

de Carvalho, M. C. C. G., Costa Nascimento, L., Darben, L. M., Polizel-Podanosqui, A. M., Lopes-Caitar, V. S., Qi, M., Rocha, C. S., Carazzolle, M. F., Kuwahara, M. K., Pereira, G. A. G., Abdelnoor, R. V., Whitham, S. A., and Marcelino-Guimarães, F. C. 2017. Prediction of the in planta Phakopsora pachyrhizi secretome and potential effector families. Mol. Plant Pathol. 18:363-377.

Deising, H., Rauscher, M., Haug, M., and Heiler, S. 1995. Differentiation and cell wall degrading enzymes in the obligately biotrophic rust fungus Uromyces viciae-fabae. Can. J. Bot. 73:624-631.

Djulic, A., Schmid, A., Lenz, H., Sharma, P., Koch, C., Wirsel, S. G. R., and Voegele, R. T. 2011. Transient transformation of the obligate biotrophic rust fungus Uromyces fabae using biolistics. Fungal Biol. 115:633-642.

Dodds, P. N., Lawrence, G. J., Catanzariti, A. M., Ayliffe, M. A., and Ellis, J. G. 2004. The Melampsora lini AvrL567 avirulence genes are expressed in haustoria and their products are recognized inside plant cells. Plant Cell 16: 755-768.

Duplessis, S., Bakkeren, G., and Hamelin, R. 2014. Advancing knowledge on biology of rust fungi through genomics. Pages 173-209 in: Advances in Botanical Research. Vol. 70. M. M. Francis, ed. Academic Press, Cambridge, MA.

Duplessis, S., Cuomo, C. A., Lin, Y.-C., Aerts, A., Tisserant, E., Veneault-Fourrey, C., Joly, D. L., Hacquard, S., Amselem, J., Cantarel, B. L., Chiu, R., Coutinho, P. M., Feau, N., Field, M., Frey, P., Gelhaye, E., Goldberg, J., Grabherr, M. G., Kodira, C. D., Kohler, A., Kües, U., Lindquist, E. A., Lucas, S. M., Mago, R., Mauceli, E., Morin, E., Murat, C., Pangilinan, J. L., Park, R., Pearson, M., Quesneville, H., Rouhier, N., Sakthikumar, S., Salamov, A. A., Schmutz, J., Selles, B., Shapiro, H., Tanguay, P., Tuskan, G. A., Henrissat, B., Van de Peer, Y., Rouzé, P., Ellis, J. G., Dodds, P. N., Schein, J. E., Zhong, S., Hamelin, R. C., Grigoriev, I. V., Szabo, L. J., and Martin, F. 2011. Obligate biotrophy features unraveled by the genomic analysis of rust fungi. Proc. Natl. Acad. Sci. USA 108: 9166-9171.

Eilam, T., Bushnell, W. R., and Anikster, Y. 1994. Relative nuclear DNA content of rust fungi estimated by flow cytometry of propidium iodidestained pycniospores. Phytopathology 84:728-735. 
El Gueddari, N. E., Rauchhaus, U., Moerschbacher, B. M., and Deising, H. B. 2002. Developmentally regulated conversion of surface-exposed chitin to chitosan in cell walls of plant pathogenic fungi. New Phytol. 156:103-112.

Fehser, S., and Moerschbacher, B. M. 2011. Expression of green fluorescent protein in the obligately biotrophic fungal plant pathogen Puccinia graminis f. sp. tritici. J. Plant Dis. Prot. 117:258-260.

Fellers, J., Soltani, B., Bruce, M., Linning, R., Cuomo, C., Szabo, L., and Bakkeren, G. 2013. Conserved loci of leaf and stem rust fungi of wheat share synteny interrupted by lineage-specific influx of repeat elements. BMC Genomics 14:60.

Fernandez, D., Tisserant, E., Talhinhas, P., Azinheira, H., Vieira, A. N. A., Petitot, A.-S., Loureiro, A., Poulain, J., Da Silva, C., Silva, M. D. O. C., and Duplessis, S. 2012. 454-pyrosequencing of Coffea arabica leaves infected by the rust fungus Hemileia vastatrix reveals in planta-expressed pathogensecreted proteins and plant functions in a late compatible plant-rust interaction. Mol. Plant Pathol. 13:17-37.

Flor, H. H. 1971. Current status of the gene-for-gene concept. Annu. Rev. Phytopathol. 9:275-296.

Geils, B. W., Hummer, K. E., and Hunt, R. S. 2010. White pines, Ribes, and blister rust: A review and synthesis. For. Pathol. 40:147-185.

Germain, H., Joly, D. L., Mireault, C., Plourde, M. B., Letanneur, C., Stewart, D., Morency, M.-J., Petre, B., Duplessis, S., and Séguin, A. 2018. Infection assays in Arabidopsis reveal candidate effectors from the poplar rust fungus that promote susceptibility to bacteria and oomycete pathogens. Mol. Plant Pathol. 19:191-200.

Goellner, K., Loehrer, M., Langenbach, C., Conrath, U., Koch, E., and Schaffrath, U. 2010. Phakopsora pachyrhizi, the causal agent of Asian soybean rust. Mol. Plant Pathol. 11:169-177.

Green, G. J. 1964. A color mutation, its inheritance, and the inheritance of pathogenicity in Puccinia graminis. Pers. Can. J. Bot. 42:1653-1664.

Guo, J., Dai, X., Xu, J.-R., Wang, Y., Bai, P., Liu, F., Duan, Y., Zhang, H., Huang, L., and Kang, Z. 2011. Molecular characterization of a Fus3/Kss1 type MAPK from Puccinia striiformis f. sp. tritici, PsMAPK1. PLoS One 6:e21895.

Gygi, S. P., Rochon, Y., Franza, B. R., and Aebersold, R. 1999. Correlation between protein and mRNA abundance in yeast. Mol. Cell. Biol. 19: 1720-1730.

Hacquard, S., Delaruelle, C., Legué, V., Tisserant, E., Kohler, A., Frey, P., Martin, F., and Duplessis, S. 2010. Laser capture microdissection of uredinia formed by Melampsora larici-populina revealed a transcriptional switch between biotrophy and sporulation. Mol. Plant-Microbe Interact. 23: 1275-1286.

Hahn, M., and Mendgen, K. 1997. Characterization of in planta-induced rust genes isolated from a haustorium -specific cDNA library. Mol. PlantMicrobe Interact. 10:427-437.

Harder, D. E., and Chong, J. 1991. Rust haustoria. Pages 235-250 in: Electron Microscopy of Plant Pathogens. K. Mendgen and D. E. Lesemann, eds. Springer-Verlag, Berlin.

Holden, R. J., and Harper, R. A. 1902. Nuclear divisions and nuclear fusions in Coleosporium sonchi-arvensis. Trans. Wis. Acad. Sci. Arts Lett. 14:63-82.

Hu, G., Kamp, A., Linning, R., Naik, S., and Bakkeren, G. 2007a. Complementation of Ustilago maydis MAPK mutants by a wheat leaf rust, Puccinia triticina homolog: Potential for functional analyses of rust genes. Mol. Plant-Microbe Interact. 20:637-647.

Hu, G., Linning, R., McCallum, B., Banks, T., Cloutier, S., Butterfield, Y., Liu, J., Kirkpatrick, R., Stott, J., Yang, G., Smailus, D., Jones, S., Marra, M., Schein, J., and Bakkeren, G. 2007b. Generation of a wheat leaf rust, Puccinia triticina, EST database from stage-specific cDNA libraries. Mol. Plant Pathol. 8:451-467.

Hu, Y., Green, G. S., Milgate, A., Stone, E. A., Rathjen, J. P., and Schwessinger, B. 2019. Pathogen detection and microbiome analysis of infected wheat using a portable DNA sequencer. Phytobiomes J. 3:92-101.

Hubbard, A., Lewis, C. M., Yoshida, K., Ramirez-Gonzalez, R. H., de Vallavieille-Pope, C., Thomas, J., Kamoun, S., Bayles, R., Uauy, C., and Saunders, D. G. O. 2015. Field pathogenomics reveals the emergence of a diverse wheat yellow rust population. Genome Biol. 16:23.

Jiao, M., Yu, D., Tan, C., Guo, J., Lan, D., Han, E., Qi, T., Voegele, R. T., Kang, Z., and Guo, J. 2017. Basidiomycete-specific PsCaMKL1 encoding a CaMK-like protein kinase is required for full virulence of Puccinia striiformis f. sp. tritici. Environ. Microbiol. 19:4177-4189.

Kamoun, S. 2006. A catalogue of the effector secretome of plant pathogenic oomycetes. Annu. Rev. Phytopathol. 44:41-60.

Kemen, E., Kemen, A. C., Rafiqi, M., Hempel, U., Mendgen, K., Hahn, M., and Voegele, R. T. 2005. Identification of a protein from rust fungi transferred from haustoria into infected plant cells. Mol. Plant-Microbe Interact. 18:1130-1139.

Kubisiak, T. L., Anderson, C. L., Amerson, H. V., Smith, J. A., Davis, J. M., and Nelson, C. D. 2011. A genomic map enriched for markers linked to
Avrl in Cronartium quercuum f. sp. fusiforme. Fungal Genet. Biol. 48: 266-274.

Lannou, C. 2012. Variation and selection of quantitative traits in plant pathogens. Annu. Rev. Phytopathol. 50:319-338.

Lanver, D., Tollot, M., Schweizer, G., Lo Presti, L., Reissmann, S., Ma, L.-S., Schuster, M., Tanaka, S., Liang, L., Ludwig, N., and Kahmann, R. 2017. Ustilago maydis effectors and their impact on virulence. Nat. Rev. Microbiol. 15:409-421.

Lawrence, G. J., Dodds, P. N., and Ellis, J. G. 2007. Rust of flax and linseed caused by Melampsora lini. Mol. Plant Pathol. 8:349-364.

Lawrence, G. J., Dodds, P. N., and Ellis, J. G. 2010. Transformation of the flax rust fungus, Melampsora lini: Selection via silencing of an avirulence gene. Plant J. 61:364-369.

Lawrence, G. J., Mayo, G. M. E., and Shepherd, K. W. 1981. Interactions between genes controlling pathogenicity in the flax rust fungus Melampsora lini. Phytopathology 71:12-19.

Lennox, C. L., and Rijkenberg, F. H. J. 1989. Scanning electron microscopy study of infection structure formation of Puccinia graminis f. sp. tritici in host and nonhost cereal species. Plant Pathol. 38:547-556.

Leonard, K. J., and Szabo, L. J. 2005. Stem rust of small grains and grasses caused by Puccinia graminis. Mol. Plant Pathol. 6:99-111.

Li, F., Upadhyaya, N. M., Sperschneider, J., Matny, O., Nguyen-Phuc, H., Mago, R., Raley, C., Miller, M. E., Silverstein, A. T., Henningsen, E., Hirsch, C. D., Visser, B., Pretorius, Z. A., Steffenson, B. J., Schwessinger, B., Dodds, P. N., and Figueroa, M. 2019. Emergence of the Ug99 lineage of the wheat stem rust pathogen through somatic hybridisation. Nat. Comm. 10:5068.

Link, T., Lohaus, G., Heiser, I., Mendgen, K., Hahn, M., and Voegele, R. T. 2005. Characterization of a novel NADP(+)-dependent D-arabitol dehydrogenase from the plant pathogen Uromyces fabae. Biochem. J. 389: 289-295.

Link, T. I., and Voegele, R. T. 2008. Secreted proteins of Uromyces fabae: Similarities and stage specificity. Mol. Plant Pathol. 9:59-66.

Liu, C., Pedersen, C., Schultz-Larsen, T., Aguilar, G. B., Madriz-Ordeñana, K., Hovmøller, M. S., and Thordal-Christensen, H. 2016. The stripe rust fungal effector PEC6 suppresses pattern-triggered immunity in a host speciesindependent manner and interacts with adenosine kinases. New Phytol. 213: 1556.

Liu, Z., Szabo, L. J., and Bushnell, W. R. 1993. Molecular cloning and analysis of abundant and stage-specific mRNAs from Puccinia graminis. Mol. Plant-Microbe Interact. 6:84-91.

Lo Presti, L., Lanver, D., Schweizer, G., Tanaka, S., Liang, L., Tollot, M., Zuccaro, A., Reissmann, S., and Kahmann, R. 2015. Fungal effectors and plant susceptibility. Annu. Rev. Plant Biol. 66:513-545.

Loegering, W. Q., and Powers, H. R. 1962. Inheritance of pathogenicity in a cross of physiologic races 111 and 36 of Puccinia graminis f. sp. tritici. Phytopathology 52:547-554.

Long, D. L., and Kolmer, J. A. 1989. A North American system of nomenclature for Puccinia recondita f. sp. tritici. Phytopathology 79:525-529.

Lorrain, C., Gonçalves dos Santos, K. C., Germain, H., Hecker, A., and Duplessis, S. 2019. Advances in understanding obligate biotrophy in rust fungi. New Phytol. 222:1190-1206.

Lorrain, C., Marchal, C., Hacquard, S., Delaruelle, C., Pétrowski, J., Petre, B., Hecker, A., Frey, P., and Duplessis, S. 2018b. The rust fungus Melampsora larici-populina expresses a conserved genetic program and distinct sets of secreted protein genes during infection of its two host plants, larch and poplar. Mol. Plant-Microbe Interact. 31:695-706.

Lorrain, C., Petre, B., and Duplessis, S. 2018a. Show me the way: Rust effector targets in heterologous plant systems. Curr. Opin. Microbiol. 46: $19-25$.

Luster, D. G., McMahon, M. B., Carter, M. L., Fortis, L. L., and Nunez, A. 2010. Proteomic analysis of germinating urediniospores of Phakopsora pachyrhizi, causal agent of Asian soybean rust. Proteomics 10:3549-3557.

Maia, T., Badel, J. L., Marin-Ramirez, G., Rocha, C. M., Fernandes, M. B., da Silva, J. C. F., de Azevedo-Junior, G. M., and Brommonschenkel, S. H. 2016. The Hemileia vastatrix effector HvEC-016 suppresses bacterial blight symptoms in coffee genotypes with the SH1 rust resistance gene. New Phytol. 213:1315-1329.

McCallum, B. D., Hiebert, C. W., Cloutier, S., Bakkeren, G., Rosa, S. B., Humphreys, D. G., Marais, G. F., McCartney, C. A., Panwar, V., Rampitsch, C., Saville, B. J., and Wang, X. 2016. A review of wheat leaf rust research and the development of resistant cultivars in Canada. Can. J. Plant Pathol. 38:1-18.

McGinnis, R. C. 1956. Cytological studies of chromosomes of rust fungi. III. The relationship of chromosome number to sexuality in Puccinia. J. Hered. 47:255-259.

McTaggart, A. R., Duong, T. A., Le, V. Q., Shuey, L. S., Smidt, W., Naidoo, S., Wingfield, M. J., and Wingfield, B. D. 2018. Chromium sequencing: The 
doors open for genomics of obligate plant pathogens. Biotechniques 65 : 253-257.

Mendgen, K. 1973. Electron microscopy of the bean rust, Uromyces phaseoli, infection structures. Phytopathol. Z. 78:109-120.

Miller, M. E., Zhang, Y., Omidvar, V., Sperschneider, J., Schwessinger, B., Raley, C., Palmer, J. M., Garnica, D., Upadhyaya, N., Rathjen, J., Taylor, J. M., Park, R. F., Dodds, P. N., Hirsch, C. D., Kianian, S. F., and Figueroa, M. 2018. De novo assembly and phasing of dikaryotic genomes from two isolates of Puccinia coronata $\mathrm{f}$. sp. avenae, the causal agent of oat crown rust. MBio 9:e01650-e01617.

Mueth, N., Ramachandran, S., and Hulbert, S. 2015. Small RNAs from the wheat stripe rust fungus (Puccinia striiformis f. sp. tritici). BMC Genomics $16: 718$.

Nazareno, E. S., Li, F., Smith, M., Park, R. F., Kianian, S. F., and Figueroa, M. 2018. Puccinia coronata f. sp. avenae: A threat to global oat production. Mol. Plant Pathol. 19:1047-1060.

Newcomb, M., Olivera, P. D., Rouse, M. N., Szabo, L. J., Johnson, J., Gale, S., Luster, D. G., Wanyera, R., Macharia, G., Bhavani, S., Hodson, D., Patpour, M., Hovmøller, M. S., Fetch, T. G., and Jin, Y. 2016. Kenyan isolates of Puccinia graminis f. sp. tritici from 2008 to 2014: Virulence to SrTmp in the Ug99 race group and implications for breeding programs. Phytopathology 106:729-736.

Nirmala, J., Drader, T., Lawrence, P. K., Yin, C., Hulbert, S., Steber, C. M., Steffenson, B. J., Szabo, L. J., von Wettstein, D., and Kleinhofs, A. 2011. Concerted action of two avirulent spore effectors activates reaction to Puccinia graminis 1 (Rpg1)-mediated cereal stem rust resistance. Proc. Natl. Acad. Sci. USA 108:14676-14681.

Nowara, D., Gay, A., Lacomme, C., Shaw, J., Ridout, C., Douchkov, D., Hensel, G., Kumlehn, J., and Schweizer, P. 2010. HIGS: Host-induced gene silencing in the obligate biotrophic fungal pathogen Blumeria graminis. Plant Cell 22:3130-3141.

Oliveira-Garcia, E., and Deising, H. B. 2013. Infection structure-specific expression of $\beta$-1,3-glucan synthase is essential for pathogenicity of Colletotrichum graminicola and evasion of $\beta$-glucan-triggered immunity in maize. Plant Cell 25:2356-2378.

Olivera, P., Newcomb, M., Szabo, L. J., Rouse, M., Johnson, J., Gale, S., Luster, D. G., Hodson, D., Cox, J. A., Burgin, L., Hort, M., Gilligan, C. A., Patpour, M., Justesen, A. F., Hovmøller, M. S., Woldeab, G., Hailu, E., Hundie, B., Tadesse, K., Pumphrey, M., Singh, R. P., and Jin, Y. 2015. Phenotypic and genotypic characterization of race TKTTF of Puccinia graminis f. sp. tritici that caused a wheat stem rust epidemic in Southern Ethiopia in 2013-14. Phytopathol. 105:917-928.

Panwar, V., Jordan, M., McCallum, B., and Bakkeren, G. 2018. Host-induced silencing of essential genes in Puccinia triticina through transgenic expression of RNAi sequences reduces severity of leaf rust infection in wheat. Plant Biotechnol. J. 16:1013-1023.

Panwar, V., McCallum, B., and Bakkeren, G. 2013a. Endogenous silencing of Puccinia triticina pathogenicity genes through in planta-expressed sequences leads to suppression of rust diseases on wheat. Plant J. 73:521-532.

Panwar, V., McCallum, B., and Bakkeren, G. 2013b. Host-induced gene silencing of wheat leaf rust fungus Puccinia triticina pathogenicity genes mediated by the barley stripe mosaic virus. Plant Mol. Biol. 81:595-608.

Pariaud, B., Ravigné, V., Halkett, F., Goyeau, H., Carlier, J., and Lannou, C. 2009. Aggressiveness and its role in the adaptation of plant pathogens. Plant Pathol. 58:409-424

Park, R. F., Golegaonkar, P. G., Derevnina, L., Sandhu, K. S., Karaoglu, H., Elmansour, H. M., Dracatos, P. M., and Singh, D. 2015. Leaf rust of cultivated barley: Pathology and control. Annu. Rev. Phytopathol. 53:565-589.

Pernaci, M., De Mita, S., Andrieux, A., Pétrowski, J., Halkett, F., Duplessis, S., and Frey, P. 2014. Genome-wide patterns of segregation and linkage disequilibrium: The construction of a linkage genetic map of the poplar rust fungus Melampsora larici-populina. Front. Plant Sci. 5:454.

Persoons, A., Morin, E., Delaruelle, C., Payen, T., Halkett, F., Frey, P., De Mita, S., and Duplessis, S. 2014. Patterns of genomic variation in the poplar rust fungus Melampsora larici-populina identify pathogenesisrelated factors. Front. Plant Sci. 5:450.

Petre, B., Joly, D. L., and Duplessis, S. 2014. Effector proteins of rust fungi. Front. Plant Sci. 5:416.

Pretsch, K., Kemen, A., Kemen, E., Geiger, M., Mendgen, K., and Voegele, R. 2013. The rust transferred proteins-A new family of effector proteins exhibiting protease inhibitor function. Mol. Plant Pathol. 14:96-107.

Qi, M., Grayczyk, J. P., Seitz, J. M., Lee, Y., Link, T. I., Choi, D., Pedley, K. F., Voegele, R. T., Baum, T. J., and Whitham, S. A. 2018. Suppression or activation of immune responses by predicted secreted proteins of the soybean rust pathogen Phakopsora pachyrhizi. Mol. Plant-Microbe Interact. 31:163-174.

Qi, M., Link, T. I., Müller, M., Hirschburger, D., Pudake, R. N., Pedley, K. F., Braun, E., Voegele, R. T., Baum, T. J., and Whitham, S. A. 2016. A small cysteine-rich protein from the Asian soybean rust fungus, Phakopsora pachyrhizi, suppresses plant immunity. PLoS Pathog 12:e1005827.

Qi, T., Zhu, X., Tan, C., Liu, P., Guo, J., Kang, Z., and Guo, J. 2017. Hostinduced gene silencing of an important pathogenicity factor PsCPK1 in Puccinia striiformis f. sp. tritici enhances resistance of wheat to stripe rust. Plant Biotechnol. J. 16:797-807.

Radhakrishnan, G. V., Cook, N. M., Bueno-Sancho, V., Lewis, C. M., Persoons, A., Mitiku, A. D., Heaton, M., Davey, P. E., Abeyo, B., Alemayehu, Y., Badebo, A., Barnett, M., Bryant, R., Chatelain, J., Chen, X., Dong, S., Henriksson, T., Holdgate, S., Justesen, A. F., Kalous, J., Kang, Z., Laczny, S., Legoff, J.-P., Lesch, D., Richards, T., Randhawa, H. S., Thach, T., Wang, M., Hovmøller, M. S., Hodson, D. P., and Saunders, D. G. O. 2019. MARPLE, a point-of-care, strain-level disease diagnostics and surveillance tool for complex fungal pathogens. BMC Biol. 17:65.

Ramachandran, S., Yin, C., Kud, J., Tanaka, K., Mahoney, A., Xiao, F., and Hulbert, S. H. 2017. Effectors from wheat rust fungi suppress multiple plant defense responses. Phytopathol. 107:75-83.

Rampitsch, C., and Bykova, N. V. 2012. Proteomics and plant disease: Advances in combating a major threat to the global food supply. Proteomics 12:673-690.

Rampitsch, C., Günel, A., Beimcik, E., and Mauthe, W. 2015. The proteome of monoclonal antibody-purified haustoria from Puccinia triticina race-1. Proteomics 15:1307-1315.

Rochi, L., José Diéguez, M., Burguener, G., Alejandro Darino, M., Fernanda Pergolesi, M., Romina Ingala, L., Romina Cuyeu, A., Turjanski, A., Domingo Kreff, E., and Sacco, F. 2018. Characterization and comparative analysis of the genome of Puccinia sorghi Schwein, the causal agent of maize common rust. Fungal Genet. Biol. 112:31-39.

Rutter, W. B., Salcedo, A., Akhunova, A., He, F., Wang, S., Liang, H., Bowden, R. L., and Akhunov, E. 2017. Divergent and convergent modes of interaction between wheat and Puccinia graminis f. sp. tritici isolates revealed by the comparative gene co-expression network and genome analyses. BMC Genomics 18:291.

Salcedo, A., Rutter, W., Wang, S., Akhunova, A., Bolus, S., Chao, S., Anderson, N., De Soto, M. F., Rouse, M., Szabo, L., Bowden, R. L., Dubcovsky, J., and Akhunov, E. 2017. Variation in the AvrSr35 gene determines $\operatorname{Sr} 35$ resistance against wheat stem rust race Ug99. Science 358: 1604-1606.

Samborski, D. J., and Dyck, P. L. 1968. Inheritance of virulence in wheat leaf rust on the standard differential wheat varieties. Can. J. Genet. Cytol. 10: 24-32.

Saunders, D. G., Win, J., Cano, L. M., Szabo, L. J., Kamoun, S., and Raffaele, S. 2012. Using hierarchical clustering of secreted protein families to classify and rank candidate effectors of rust fungi. PLoS One 7:e29847.

Savary, S., Willocquet, L., Pethybridge, S. J., Esker, P., McRoberts, N., and Nelson, A. 2019. The global burden of pathogens and pests on major food crops. Nat. Ecol. Evol. 3:430-439.

Schillberg, S., Tiburzy, R., and Fischer, R. 2000. Transient transformation of the rust fungus Puccinia graminis f. sp. tritici. Mol. Gen. Genet. 262: 911-915.

Schwessinger, B., Sperschneider, J., Cuddy, W. S., Garnica, D. P., Miller, M. E., Taylor, J. M., Dodds, P. N., Figueroa, M., Park, R. F., and Rathjen, J. P. 2018. A near-complete haplotype-phased genome of the dikaryotic wheat stripe rust fungus Puccinia striiformis f. sp. tritici reveals high interhaplotype diversity. MBio 9:e02275-17.

Singh, R. P., Hodson, D. P., Jin, Y., Lagudah, E. S., Ayliffe, M. A., Bhavani, S., Rouse, M. N., Pretorius, Z. A., Szabo, L. J., Huerta-Espino, J., Basnet, B. R., Lan, C., and Hovmøller, M. S. 2015. Emergence and spread of new races of wheat stem rust fungus: Continued threat to food security and prospects of genetic control. Phytopathology 105:872-884.

Sniezko, R., Smith, J., Liu, J.-J., and Hamelin, R. 2014. Genetic resistance to fusiform rust in Southern pines and white pine blister rust in white pines-a contrasting tale of two rust pathosystems-current status and future prospects. Forests 5:2050-2083.

Song, X., Rampitsch, C., Soltani, B., Mauthe, W., Linning, R., Banks, T., McCallum, B., and Bakkeren, G. 2011. Proteome analysis of wheat leaf rust fungus, Puccinia triticina, infection structures enriched for haustoria. Proteomics 11:944-963

Sperschneider, J., Catanzariti, A.-M., DeBoer, K., Petre, B., Gardiner, D. M., Singh, K. B., Dodds, P. N., and Taylor, J. M. 2017. LOCALIZER: Subcellular localization prediction of both plant and effector proteins in the plant cell. Sci. Rep. 7:44598.

Sperschneider, J., Dodds, P. N., Gardiner, D. M., Singh, K. B., and Taylor, J. M. 2018b. Improved prediction of fungal effector proteins from secretomes with EffectorP 2.0. Mol. Plant Pathol. 19:2094-2110.

Sperschneider, J., Dodds, P. N., Singh, K. B., and Taylor, J. M. 2018a. ApoplastP: Prediction of effectors and plant proteins in the apoplast using machine learning. New Phytol. 217:1764-1778. 
Sperschneider, J., Jacques, S., Xu, B., Upadhyaya, N. M., Mago, R., Singh, K. B., Stone, E. A., Wang, M.-B., Dodds, P. N., and Taylor, J. M. 2018c. The stem rust fungus Puccinia graminis f. sp. tritici induces waves of small RNAs with opposing profiles during wheat infection. bioRxiv 469338.

Staples, R. C. 2000. Research on the rust fungi during the twentieth century. Annu. Rev. Phytopathol. 38:49-69.

Statler, G. D. 1979. Inheritance of pathogenicity of culture 70-1, race 1, of Puccinia recondita tritici leaf rust of wheat. Phytopathology 69:661-663.

Statler, G. D. 2000. Inheritance of virulence of Puccinia triticina culture X47, the F1 of the cross 71-112 × 70-1. Can. J. Plant Pathol. 22:276-279.

Stone, C. L., McMahon, M. B., Fortis, L. L., Nunez, A., Smythers, G. W., Luster, D. G., and Frederick, R. D. 2012. Gene expression and proteomic analysis of the formation of Phakopsora pachyrhizi appressoria. BMC Genomics 13:269.

Struck, C., Ernst, M., and Hahn, M. 2002. Characterization of a developmentally regulated amino acid transporter (AAT1p) of the rust fungus Uromyces fabae. Mol. Plant Pathol. 3:23-30.

Struck, C., Mueller, E., Martin, H., and Lohaus, G. 2004. The Uromyces fabae UfAAT3 gene encodes a general amino acid permease that prefers uptake of in planta scarce amino acids. Mol. Plant Pathol. 5:183-189.

Struck, C., Siebels, C., Rommel, O., Wernitz, M., and Hahn, M. 1998. The plasma membrane $\mathrm{H}(+)$-ATPase from the biotrophic rust fungus Uromyces fabae: Molecular characterization of the gene (PMA1) and functional expression of the enzyme in yeast. Mol. Plant-Microbe Interact. 11:458-465.

Talhinhas, P., Batista, D., Diniz, I., Vieira, A., Silva, D. N., Loureiro, A., Tavares, S., Pereira, A. P., Azinheira, H. G., Guerra-Guimarães, L., Várzea, V., and Silva, M. C. 2017. The coffee leaf rust pathogen Hemileia vastatrix: One and a half centuries around the tropics. Mol. Plant Pathol. 18:1039-1051.

Tavares, S., Ramos, A. P., Pires, A. S., Azinheira, H. G., Caldeirinha, P., Link, T., Abranches, R., Silva, M. D. C. M. L., Voegele, R. T., Loureiro, J., and Talhinhas, P. 2014. Genome size analyses of Pucciniales reveal the largest fungal genomes. Front. Plant Sci. 5:422.

Thara, V. K., Fellers, J. P., and Zhou, J. M. 2003. In planta induced genes of Puccinia triticina. Mol. Plant Pathol. 4:51-56.

Toome-Heller, M. 2016. Latest developments in the research of rust fungi and their allies (Pucciniomycotina). Pages 147-168 in: Biology of Microfungi. D.-W. Li, ed. Springer International Publishing, Cham.

Upadhyaya, N. M., Mago, R., Staskawicz, B. J., Ayliffe, M. A., Ellis, J. G., and Dodds, P. N. 2014. A bacterial type III secretion assay for delivery of fungal effector proteins into wheat. Mol. Plant-Microbe Interact. 27:255-264.

Vittal, R., Yang, H.-C., and Hartman, G. L. 2012. Anastomosis of germ tubes and migration of nuclei in germ tube networks of the soybean rust pathogen, Phakopsora pachyrhizi. Eur. J. Plant Pathol. 132:163-167.

Voegele, R. T. 2006. Uromyces fabae: Development, metabolism, and interactions with its host Vicia faba. FEMS Microbiol. Lett. 259:165-173.

Voegele, R. T., Hahn, M., and Mendgen, K. 2009. The Uredinales: Cytology, biochemistry, and molecular biology. Pages 69-98 in: Plant Relationships; The Mycota. V. H. B. Deising, ed. Springer, Berlin, Heidelberg.

Voegele, R. T., Struck, C., Hahn, M., and Mendgen, K. 2001. The role of haustoria in sugar supply during infection of broad bean by the rust fungus Uromyces fabae. Proc. Natl. Acad. Sci. USA 98:8133-8138.

Voegele, R. T., Wirsel, S., Moell, U., Lechner, M., and Mendgen, K. 2006. Cloning and characterization of a novel invertase from the obligate biotroph Uromyces fabae and analysis of expression patterns of host and pathogen invertases in the course of infection. Mol. Plant-Microbe Interact. 19: 625-634

Wang, B., Sun, Y., Song, N., Zhao, M., Liu, R., Feng, H., Wang, X., and Kang, Z. 2017. Puccinia striiformis f. sp. tritici microRNA-like RNA 1 (Pst-milR1), an important pathogenicity factor of Pst, impairs wheat resistance to Pst by suppressing the wheat pathogenesis-related 2 gene. New Phytol. 215:338-350.

Wang, L., Zheng, D., Zuo, S., Chen, X., Zhuang, H., Huang, L., Kang, Z., and Zhao, J. 2018. Inheritance and linkage of virulence genes in Chinese predominant race CYR32 of the wheat stripe rust pathogen Puccinia striiformis f. sp. tritici. Front. Plant Sci. 9:120.
Wang, X., and McCallum, B. 2009. Fusion body formation, germ tube anastomosis, and nuclear migration during the germination of urediniospores of the wheat leaf rust fungus, Puccinia triticina. Phytopathology 99: 1355-1364.

Watson, I. A., and Luig, N. H. 1958. Somatic hybridisation in Puccinia graminis f. sp. tritici. Proc. Linn. Soc. N. S. W. 83:190-195.

Webb, C. A., Szabo, L. J., Bakkeren, G., Garry, C., Staples, R. C., Eversmeyer, M., and Fellers, J. P. 2006. Transient expression and insertional mutagenesis of Puccinia triticina using biolistics. Funct. Integr. Genomics 6:250-260.

Westerink, N., Roth, R., Van den Burg, H. A., De Wit, P. J., and Joosten, M. H. 2002. The AVR4 elicitor protein of Cladosporium fulvum binds to fungal components with high affinity. Mol. Plant-Microbe Interact. 15:1219-1227.

Williams, N. D., Gough, F. J., and Rondon, M. R. 1966. Interaction of pathogenicity genes in Puccinia graminis f. sp. tritici and reaction genes in Triticum aestivum ssp. vulgare 'Marquis' and 'Reliance'. Crop Sci. 6: 245-248.

Wirsel, S. G. R., Voegele, R. T., Baenninger, R., and Mendgen, K. W. 2004. Cloning of beta-tubulin and succinate dehydrogenase genes from Uromyces fabae and establishing selection conditions for their use in transformation. Eur. J. Plant Pathol. 110:767-777.

Wu, J. Q., Sakthikumar, S., Dong, C., Zhang, P., Cuomo, C. A., and Park, R. F. 2017. Comparative genomics integrated with association analysis identifies candidate effector genes corresponding to $\mathrm{Lr} 20$ in phenotype-paired Puccinia triticina isolates from Australia. Front. Plant Sci. 8:148.

Xu, J., Linning, R., Fellers, J., Dickinson, M., Zhu, W., Antonov, I., Joly, D. L., Donaldson, M. E., Eilam, T., Anikster, Y., Banks, T., Munro, S., Mayo, M., Wynhoven, B., Ali, J., Moore, R., McCallum, B., Borodovsky, M., Saville, B., and Bakkeren, G. 2011. Gene discovery in EST sequences from the wheat leaf rust fungus Puccinia triticina sexual spores, asexual spores and haustoria, compared to other rust and corn smut fungi. BMC Genomics 12: 161.

Xuei, X. L., Bhairi, S., Staples, R. C., and Yoder, O. C. 1993. INF56 represents a family of differentiation-specific genes from Uromyces appendiculatus. Curr. Genet. 24:84-88.

Yin, C., Chen, X., Wang, X., Han, Q., Kang, Z., and Hulbert, S. 2009. Generation and analysis of expression sequence tags from haustoria of the wheat stripe rust fungus Puccinia striiformis f. sp. tritici. BMC Genomics 10:626.

Yin, C., Downey, S. I., Klages-Mundt, N. L., Ramachandran, S., Chen, X., Szabo, L. J., Pumphrey, M., and Hulbert, S. H. 2015. Identification of promising host-induced silencing targets among genes preferentially transcribed in haustoria of Puccinia. BMC Genomics 16:579.

Yin, C., Jurgenson, J. E., and Hulbert, S. H. 2011. Development of a hostinduced RNAi system in the wheat stripe rust fungus Puccinia striiformis $\mathrm{f}$. sp. tritici. Mol. Plant-Microbe Interact. 24:554-561.

Yin, C., Ramachandran, S. R., Zhai, Y., Bu, C., Pappu, H. R., and Hulbert, S. H. 2019. A novel fungal effector from Puccinia graminis suppressing RNA silencing and plant defense responses. New Phytol. 222:1561-1572.

Zambino, P. J., Kubelik, A. R., and Szabo, L. J. 2000. Gene action and linkage of avirulence genes to DNA markers in the rust fungus Puccinia graminis. Phytopathology 90:819-826.

Zhang, H., Fu, Y., Guo, H., Zhang, L., Wang, C., Song, W., Yan, Z., Wang, Y., and Ji, W. 2019. Transcriptome and proteome-based network analysis reveals a model of gene activation in wheat resistance to stripe rust. Int. J. Mol. Sci. 20:1106.

Zhao, M., Wang, J., Ji, S., Chen, Z., Xu, J., Tang, C., Chen, S., Kang, Z., and Wang, X. 2018. Candidate effector Pst_8713 impairs the plant immunity and contributes to virulence of Puccinia striiformis f. sp. tritici. Front. Plant Sci. 9:1294.

Zhu, X., Jiao, M., Guo, J., Liu, P., Tan, C., Yang, Q., Zhang, Y., Thomas Voegele, R., Kang, Z., and Guo, J. 2018. A novel MADS-box transcription factor PstMCM1-1 is responsible for full virulence of Puccinia striiformis f. sp. tritici. Environ. Microbiol. 20:1452-1463. 